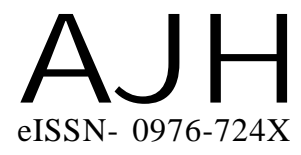

Article history :

Received : 06.06.2017

Revised : 01.11.2017

Accepted : 08.11.2017

Members of the Research Forum

Associated Authors:

${ }^{1}$ Department of Agriculture,

Bhagwant University, AJMER

(RAJASTHAN) INDIA

${ }^{2}$ Department of Agricultural

Biotechnology Bhagwant University,

AJMER (RAJASTHAN) INDIA

Author for correspondence :

TEKCHAND CHHABA

Department of Agriculture,

Bhagwant University, AJMER

(RAJASTHAN) INDIA

Email : tcchhaba199@gmai.com
THEASIAN JOURNALOF HORTICULTURE
Volume $\mathbf{1 2} \mid$ Issue $2 \mid$ December, 2017| 169-184
Visit us -www.researchjournal.co.in

RESEARCH PAPER

DOI : 10.15740/HAS/TAJH/12.2/169-184

\section{Response of mustard to potassium in combination with other nutrients}

\section{TEKCHAND CHHABA, DEVENDRA SINGH ${ }^{1}$ AND BHANWAR LAL JAT ${ }^{2}$}

ABSTRACT : Plant height and number of primary and secondary branches at different crop growth stages were not affected significantly due to different nutrient levels, however exhibited some improvement over control. Dry matter accumulation by individual plant increased with advancement in cropage till harvest. The highest dry matter accumulation were recorded at $100 \%$ NPK + S @ 40kg/ha treatment. 100\% NPK + FYM @ 2.5 t/ha (dry weight) and 100\% NPK $+\mathrm{ZnSO}_{4} @ 25 \mathrm{~kg} / \mathrm{ha}$ ranked second and third, respectively in dry matter accumulation after $100 \%$ NPK + S @ 40kg/ha. Days taken to 50\% flowering and 80\% maturity remained unaffected by different nutrient application levels. $100 \% \mathrm{NPK}+\mathrm{S} @ 40 \mathrm{~kg} / \mathrm{ha}$ recorded significantly higher number of total branches at harvest than remaining treatments. 100\% NPK + Borax @ 0.2\% (foliar) and 100\% NPK + FYM @ 2.5t/ha (dry weight) recorded next higher to values 100\% NPK + S @ 40kg/ha. Yield attributes viz. number of siliquae per plant, length of siliqua, 1000- seed weight and seed weight per plant were affected significantly due to different nutrient levels. $150 \%$ NPK recorded higher number of siliquae per plant, higher number of seeds per siliqua, length of siliqua, 1000- seed weight and seed weight per plant. 150\% NPK recorded significantly higher values of seed, stover and biological yield per hectare than remaining treatments. This treatment was followed by $100 \%$ NPK + FYM @ 2.5t/ha (dry weight). Harvest index did not differ significantly under different nutrient levels. The nutrients (N, P and K) concentration in seed and stover remained unaffected by different nutrient levels. The nutrients (N, P and $\mathrm{K}$ ) uptake by seed, stover and crop was recorded maximum at $150 \%$ NPK. The protein content in seed was found non- significant under different nutrient levels. However, it was recorded maximum at $100 \%$ NP treatment. The protein yield was found maximum at $150 \%$ NPK. The oil content in seed was found non- significant under different nutrient levels. Oil yield in seed was recorded maximum at $150 \%$ NPK. The maximum net returns and gross return were recorded at $150 \%$ NPK. Highest return per rupee invested was recorded at $150 \%$ NPK which was followed by $50 \%$ NPK. However, the lowest return per rupee invested was recorded in control condition.

KEY WORDS : Borax, FYM, NPK, Plant height, DAS

HOW TO CITE THIS ARTICLE : Chhaba, Tekchand, Singh, Devendra and Jat, Bhanwar Lal (2017). Response of mustard to potassium in combination with other nutrients. Asian J. Hort., 12(2) : 169-184, DOI : 10.15740/HAS/TAJH/12.2/169-184. 